\title{
WHY IS THERE SO LITTLE LITIGATION UNDER FREE TRADE AGREEMENTS? RETALIATION AND ADJUDICATION IN INTERNATIONAL DISPUTE SETTLEMENT
}

\section{Geraldo Vidigal $^{\mathrm{a}}$}

\begin{abstract}
Over the past decade, the WTO dispute settlement system has continued to be used extensively, contrasting with the very few disputes taken to inter-state adjudication under FTAs. This paper discusses the causes of this discrepancy, arguing that, besides specific procedural difficulties, it may be explained by a more structural difference between adjudication in a multilateral and in a bilateral setting. The WTO's global scope and the collective surveillance established by the DSU ensure that findings of breach harm a wrongdoer's reputation and mobilize community pressure for compliance. Because adjudication within an FTA cannot mobilize the same multilateral forces, it may not only be less effective than WTO adjudication - it may also be perceived as less effective than unilateral retaliation.
\end{abstract}

\footnotetext{
${ }^{a}$ Assistant Professor, Faculty of Law, University of Amsterdam. This paper was written while the author was Visiting Fellow at the Centre for Trade and Economic Integration, Graduate Institute, Geneva, and presented at the G2 Annual WTO Conference in Geneva in July 2017. I thank Joost Pauwelyn, researchers at the Graduate Institute and conference participants for comments on earlier versions. All errors are mine. E-mail: g.vidigal@uva.nl.
}

(C) The Authors. All rights reserved. 
CTEI Working Papers describe research in progress by the author(s) and are published to elicit comments and to further debate. No part of this paper may be reproduced without the permission of the authors.

\section{Centre for Trade and Economic Integration (CTEI)}

The Centre for Trade and Economic Integration fosters world-class multidisciplinary scholarship aimed at developing solutions to problems facing the international trade system and economic integration more generally. It works in association with public sector and private sector actors, giving special prominence to Geneva-based International Organisations such as the WTO and UNCTAD. The Centre also bridges gaps between the scholarly and policymaking communities through outreach and training activities in Geneva.

www.graduateinstitute.ch/ctei 


\section{Introduction}

Ever since the World Trade Organization (WTO) was established in 1995, its dispute settlement system has been considered its crown jewel. Members have ensured the centrality of dispute settlement in the governance of their trade relations by continuing to bring disputes, including sensitive ones, for adjudication pursuant to the provisions of the Dispute Settlement Understanding (DSU). In the ten years between 2007 and 2016, WTO Members requested consultations 169 times, leading to the establishment of 149 panels. In the same period, the Dispute Settlement Body (DSB) adopted 64 original dispute settlement reports and 13 reports on compliance, and issued 5 authorizations for suspension of concession and other obligations. Although fewer disputes are now initiated per year than were in the early years of the organization, ${ }^{2}$ WTO adjudication is still by far the most used inter-state adjudication system. By comparison, in the same period only 26 claims were filed before the International Court of Justice.

The vitality of WTO dispute settlement contrasts with the virtual idleness of inter-state dispute settlement mechanisms established under free trade agreements (FTAs), signed between pairs (or groups) of countries to promote liberalization and economic integration between them. ${ }^{3}$ Over the same time period (2007-2016), the sole case of inter-state litigation on trade successfully initiated and completed under an FTA was the Costa Rica v EI Salvador dispute, under the Dominican Republic - Central America - United States Free Trade Agreement (CAFTA-DR). ${ }^{4}$ A labor dispute, initiated by the United States against Guatemala in 2010, was adjudicated in 2017 under the same FTA. ${ }^{5}$

This paper discusses the contrast between the vigor of the WTO dispute settlement system and the virtual paralysis of dispute settlement under FTAs, arguing that it is due not only to procedural legal reasons (which make FTA adjudication less predictable) but also to the multilateral character of WTO adjudication. In addition to making WTO adjudication more

\footnotetext{
${ }^{2}$ Louise Johannesson and Petros Mavroidis, 'The WTO Dispute Settlement System 1995-2016: A Data Set and Its Descriptive Statistics', 41 Journal of World Trade (2017) 357.

${ }^{3}$ The WTO website labels these agreements Regional Trade Agreements (RTAs). Others, such as Jagdish Bhagwati, prefer to call them preferential trade agreements (PTAs). Most of these agreements are labelled free trade agreements (FTAs). This paper uses the latter denomination.

${ }^{4}$ Informe Final del Grupo Arbitral, Costa Rica vs El Salvador - Tratamiento Arancelario a Bienes Originarios de Costa Rica, 18 November 2014 (CAFTA-DR/ARB/2014/CR-ES/17).

${ }^{5}$ Final Report of the Panel, Guatemala - Issues Relating to the Obligations Under Article 16.2.1(a) of the CAFTA$D R, 14$ June 2017.
} 
attractive than FTA adjudication when both are available, this multilateral aspect may be instrumental in making adjudication more attractive than unilateral retaliation as a means of exerting pressure on a wrongdoer to comply with the underlying agreement.

The argument proceeds as follows. Section 2 examines WTO disputes between Members that are parties to FTAs over the period 2007-2016, discussing the reasons for these disputes to have been brought before the WTO rather than under the FTA. Section 3 argues that, besides procedural legal reasons specific to each FTA, a broader reason explains the lack of FTA disputes: the absence of the multilateral enforcement pressure that is integral to WTO adjudication. As a result, FTA parties may be tempted to retaliate unilaterally rather than take their disputes to adjudication. Section 4 examines the practice of WTO dispute settlement with respect to retaliation, showing that retaliation is used as a threat but, when authorized, is rarely applied. The real strength of WTO dispute settlement is not in the authorization for retaliation but in the adjudication process that precedes it. Section 5 concludes.

\section{WTO disputes between FTA partners and the lack of FTA disputes}

WTO Members clearly find it advantageous to enter into FTAs. The WTO FTA database currently lists 296 trade agreements in force. Of these, 169 entered into force after 2005, and 90 after $2010 .{ }^{6}$ This proliferation of FTAs has not been accompanied by a comparable increase in FTA litigation. While FTAs have been used as a basis for a number of investorstate disputes (and, in some cases, other types of disputes initiated by private parties), very few cases of inter-state FTA litigation exist. The 2011 World Trade Report of the WTO found that 'the vast majority of provisions in regional and bilateral trade agreements are never the subject of any dispute settlement proceedings, even where a right to invoke proceedings exists'. $^{7}$ In 2014, Petros Mavroidis and André Sapir concluded that the signature of a FTA with the EU or US leads to a decrease in WTO litigation between the parties, but not to the appearance of new disputes under the FTA. ${ }^{8}$

\footnotetext{
${ }^{6}$ http://rtais.wto.org/UI/PublicMaintainRTAHome.aspx, accessed 10.7.2017.

${ }^{7}$ WTO, 2011 World Trade Report, at 130.

${ }^{8}$ Petros C. Mavroidis and André Sapir, 'Dial FTAs for Peace: The Influence of Preferential Trade Agreements on Litigation between Trading Partners' (2014), http://indianeconomy.columbia.edu/sites/default/files/paper4dial ptas for peace.pdf, accessed 10.7.2017.
} 
Except for the two disputes successfully adjudicated under CAFTA-DR, ${ }^{9}$ this situation has not changed. Dispute settlement under Chapter 20 of the North American Free Trade Agreement (NAFTA), which led to three panel reports between 1996 and 2001, ${ }^{10}$ became completely idle after the United States de facto blocked the composition of a panel in its dispute with Mexico concerning sugar imports. ${ }^{11}$ In the Common Market of the South (Mercosur), ten arbitral awards concerning trade barriers were issued under the Brasília Protocol (19932004). ${ }^{12}$ After the creation of a Permanent Mercosur Tribunal in 2004, only two trade disputes were taken to adjudication, in 2005 and 2006, leading to a total of seven awards. After the last of these awards was issued in 2008, Mercosur dispute settlement would have remained entirely idle were it not for a 2012 request concerning a non-trade dispute, promptly considered inadmissible. ${ }^{13}$

Adjudication has also seen significant use in regional agreements in Africa and the Americas that allow individuals to bring claims to international courts. ${ }^{14}$ Additionally, two labor disputes were initiated by the United States, against Guatemala in 2010 (under CAFTA-DR) and against Bahrain in 2011 (under the US-Bahrain FTA). ${ }^{15}$ To find another case of an interstate trade dispute under an FTA, one must go back more than 25 years to a 1991 panel report issued under the 1985 US-Israel FTA. ${ }^{16}$

Making a comprehensive assessment of the reasons for this state of affairs is challenging. Many variables may influence a decision not to bring a dispute, and gathering information on disputes that were never formally brought before a dispute settlement mechanism

\footnotetext{
${ }^{9}$ Notes 4 and 5 above.

${ }^{10}$ https://www.nafta-sec-alena.org/Home/Dispute-Settlement/Decisions-and-Reports

11 Joost H. B. Pauwelyn, "Adding Sweeteners to Softwood Lumber: The WTO-NAFTA "Spaghetti Bowl" Is Cooking' 9 Journal of International Economic Law (2006) 1.

12 http://www.tprmercosur.org/es/sol contr laudos br.htm, accessed 10.7.2017.

13 http://www.tprmercosur.org/pt/sol contr laudos.htm, accessed 10.7.2017. The 2012 dispute concerned the suspension of Paraguay's decision-making powers by Brazil, Argentina and Uruguay, immediately followed by the incorporation of Venezuela into the bloc.

${ }^{14}$ James T. Gathii, 'The Under-Appreciated Jurisprudence of African Regional Trade Judiciaries', 12 Oregon Review of International Law (2010) 245; Karen J. Alter and Laurence R. Helfer, Transplanting International Courts: The Law and Politics of the Andean Tribunal of Justice (OUP 2017); Salvatore Caserta and Mikael Rask Madsen, 'Between Community Law and Common Law: The Rise of the Caribbean Court of Justice at the Intersection of Regional Integration and Post-Colonial Legacies', iCourts Working Paper Series, No. 10 (2016), available at https://papers.ssrn.com/sol3/papers.cfm?abstract_id=2528978

${ }^{15}$ https://ustr.gov/issue-areas/labor/bilateral-and-regional-trade-agreements/, accessed 10.7.2017.

${ }_{16}$ The panel report itself is not public. See Gary N. Horlick and F. Amanda DeBusk, 'Dispute Resolution Panels of the U.S.-Canada Free Trade Agreement: The First Two and One-half Years, 37 McGill Law Journal (1992) 574, 579 (footnote 23);
} 
presents obvious difficulties. ${ }^{17}$ As a first step, it is possible to know at least the disputes between WTO Members that are parties to FTAs that were brought to the WTO, and to discuss the reasons why these disputes were not brought before the relevant FTA. These are as follows:

Table 1 - WTO disputes between FTA partners since 2007

\begin{tabular}{|c|c|}
\hline FTA & Dispute \\
\hline NAFTA & $\begin{array}{l}\text { US - Supercalendered Paper (DS505) } \\
\text { US - Agriculture Subsidies (DS357) } \\
\text { US - COOL (DS384, DS386) } \\
\text { Canada - Wine (DS520) } \\
\text { US - Tuna II (Mexico) (DS381) }\end{array}$ \\
\hline CAFTA-DR & $\begin{array}{l}\text { Dominican Republic - Safeguards (DS415, DS416, } \\
\text { DS417, DS418) }\end{array}$ \\
\hline Mexico - Central America FTA & Costa Rica - Avocados (524) \\
\hline $\begin{array}{l}\text { Latin American Integration Association (ALADI) } \\
\text { Economic Complementation Agreement no. } 35 \\
\text { (Mercosur-Chile) }\end{array}$ & Chile - Wheat Flour from Argentina (DS393) \\
\hline $\begin{array}{l}\text { ALADI Economic Complementation Agreement no. } \\
38 \text { (Mercosur - Peru) }\end{array}$ & Argentina - Fasteners and Chains from Peru (DS410) \\
\hline $\begin{array}{l}\text { ALADI Partial Scope Agreement between Panama } \\
\text { and Colombia }\end{array}$ & $\begin{array}{l}\text { Colombia - Textiles (DS461) } \\
\text { Colombia - Ports of Entry (DS366) }\end{array}$ \\
\hline $\begin{array}{l}\text { ALADI Economic Complementation Agreement no. } 6 \\
\text { (Argentina-Mexico) }\end{array}$ & Argentina - Import Measures (DS446) \\
\hline $\begin{array}{l}\text { Trade Agreement between the European Union and } \\
\text { Colombia and Peru }\end{array}$ & Colombia - Spirits (DS502) \\
\hline Agreement on the European Economic Area & EC - Seal Products (Norway) (DS401) \\
\hline Moldova - Ukraine FTA & Ukraine - Distilled Spirits (DS423) \\
\hline
\end{tabular}

\footnotetext{
${ }^{17}$ On some of these disputes, see Davis, note_above.
} 


\begin{tabular}{|c|c|}
\hline & Moldova - Environmental Charge (DS421) \\
\hline Armenia - Ukraine FTA & Armenia - Cigarettes and Alcoholic Beverages (DS411) \\
\hline Commonwealth of Independent States FTA (CISFTA) & $\begin{array}{l}\text { Ukraine - Measures relating to Trade in Goods and } \\
\text { Services (DS525) } \\
\text { Russia - Traffic in Transit (DS512) } \\
\text { Russia - Railway Equipment (DS499) } \\
\text { Ukraine - Ammonium Nitrate (Russia) (DS493) }\end{array}$ \\
\hline US - Korea FTA (KORUS) & $\begin{array}{l}\text { US - OCTG (Korea) (DS488) } \\
\text { US - Washing Machines (DS464) }\end{array}$ \\
\hline India - Japan FTA & India - Iron and Steel Products (DS518) \\
\hline Association of Southeast Asian Nations (ASEAN) & $\begin{array}{l}\text { Indonesia - Iron or Steel Products (Viet Nam) (DS496) } \\
\text { Thailand - Cigarettes (Philippines) (DS371) }\end{array}$ \\
\hline ASEAN - Australia - New Zealand FTA (AANZFTA) & $\begin{array}{l}\text { Indonesia - Import Licensing Regimes (New Zealand) } \\
\text { (DS477)* } \\
\text { Australia - Tobacco Plain Packaging (Indonesia) } \\
\text { (DS467) }\end{array}$ \\
\hline $\begin{array}{l}\text { Australia - New Zealand Closer Economic Relations } \\
\text { Trade Agreement (ANZCERTA) }\end{array}$ & Australia - Apples (DS367) \\
\hline
\end{tabular}

* A request for consultations was submitted on substantially the same matter (DS466) and never led to the establishment of a panel.

Examining these disputes, two types of reasons appear to prevail in the decision to resort to WTO adjudication rather than FTA adjudication. First, the lack of a clear and predictable procedure leading to a decision within a reasonable time makes most FTA dispute settlement mechanisms less reliable than WTO dispute settlement. Second, , even where a decision can in principle be obtained within a similar time, the reduced ability of FTA dispute settlement to produce the impact a WTO condemnatory report produces may make recourse to FTA dispute settlement appear less useful than recourse to the WTO.

\section{A. Procedural legal reasons: lack or weakness of third-party dispute settlement}

A key reason why many disputes are brought before the WTO rather than an FTA is the predictability of the WTO dispute settlement procedure, and the certainty of obtaining a 
high-quality report within a reasonable period of time. Many FTAs simply do not feature a dispute settlement mechanism that a complainant can resort to unilaterally, or do not allow certain disputes to be brought under the FTA dispute settlement mechanism. Potential FTA disputes 'lost' to the WTO between 2007 and 2016 for lack of compulsory third-party dispute settlement in the FTA include Australia - Apples (for ANZCERTA), ${ }^{18}$ Colombia - Textiles and Colombia - Ports of Entry (ALADI Partial Agreement between Colombia and Panama), ${ }^{19}$ Ukraine - Distilled Spirits and Moldova - Environmental Charge (Ukraine - Moldova FTA), ${ }^{20}$ and Armenia - Cigarettes and Alcoholic Beverages (Armenia - Ukraine FTA). ${ }^{21}$ Ukraine's non-adherence to the 1991 Economic Court of the Commonwealth of Independent States meant that the four WTO disputes between Russia and Ukraine could not be taken to that Court and were brought to the WTO. ${ }^{22}$ The two disputes between Korea and the United States initiated since the US-Korea FTA entered into force concerned anti-dumping matters, specifically not covered by the FTA. ${ }^{23}$

Other FTAs feature dispute settlement mechanisms that are in principle compulsory but that may in practice be blocked by a defendant, usually because the defendant's cooperation is required for composing the panel or arbitral tribunal. Most prominently, NAFTA Chapter 20 adjudication has been blocked since the United States failed to cooperate in the composition of the panel requested by Mexico in 2000 to solve a dispute concerning its sugar exports to the US. $^{24}$ On the other hand, between 2007 and 2016 NAFTA parties have started

\footnotetext{
${ }^{18}$ Australia - New Zealand Closer Economic Relations Trade Agreement, signed 31.8.1965, entered into force 1.1.1966.

${ }^{19}$ Acuerdo de Alcance Parcial Suscrito Al Amparo del Artículo 25 del Tratado de Montevideo de 1980, entre la Republica de Colombia y la Republica de Panama, signed 9.7.1993, entered into force 18.1.1995.

${ }^{20}$ Free Trade Agreement between the Cabinet of Ministers of Ukraine and the Government of the Republic of Moldova, signed 13.11.2003, entered into force 19.5.2005.

${ }^{21}$ Agreement between the Government of Republic of Armenia and the Government of Ukraine on Free Trade, signed 7.10.1994, entered into force 18.12.1996.

${ }^{22}$ Ukraine - Ammonium Nitrate (Russia) (DS493), Russia - Railway Equipment (DS499), Russia - Traffic in Transit (DS512) and Ukraine - Measures relating to Trade in Goods and Services (DS525). On 16.12.2015, Russia unilaterally suspended the application of the CIS FTA between itself and Ukraine, potentially affecting the applicability of the FTA to the two latter disputes. It is unclear whether this suspension is supported either by the CIS FTA or by Article 60 of the Vienna Convention on the Law of Treaties.

${ }^{23}$ US - Washing Machines (DS464) and US - OCTG (Korea) (DS488). The US - Carbon Steel (Korea) (DS420) and US - Zeroing (Korea) (DS402) disputes were initiated during the period researched but before the US - Korea FTA entered into force. The same holds for Korea - Bovine Meat (Canada), initiated in 2009, since the Canada Korea FTA entered into force in 2015 only. It is also the case of the last incarnations of EC - Bananas (DS361 and DS364), since these disputes were brought by Colombia and Panama in 2007, and both the EU Colombia/Peru FTA and the EU - Central America Association Agreement entered into force only in 2013.

${ }^{24}$ See Pauwelyn, n11 above.
} 
consultations against each other in the WTO no less than six times. ${ }^{25}$ Three of these requests - the two in US - COOL and the one in US - Tuna II (Mexico) - went through all the stages of a dispute provided for in the DSU, from consultations to adjudication to authorized retaliation. The same difficulty with composing a panel, or the prospect of it occurring, may have prevented the other disputes from being brought under FTAs: Costa Rica - Avocados under the Mexico - Costa Rica FTA, ${ }^{26}$ and Chile - Wheat Flour from Argentina under the Chile - Mercosur Economic Complementation Agreement. ${ }^{27}$

In other cases, FTA dispute settlement could in principle have been used but no precedent exists for a dispute. A Member that initiated a dispute would be 'testing' the dispute settlement mechanism under the relevant agreement, with the result being potentially unexpected delays or reports of lower quality that they could have obtained by resorting to WTO adjudication. This is the case of disputes between parties to trade agreements signed under the umbrella of ALADI: the Peruvian request in Argentina - Anti-Dumping Duties on Fasteners and Chains from Peru ${ }^{28}$ and Mexico's complaint in Argentina - Import Measures. ${ }^{29}$ Other disputes in this category are India - Iron and Steel Products (under the India - Japan FTA), ${ }^{30}$ Indonesia - Iron or Steel Products (Viet Nam) (ASEAN Charter), ${ }^{31}$ and Thailand Cigarettes (Philippines) (ASEAN Protocol on Enhanced Dispute Settlement Mechanism), ${ }^{32}$ as well as Indonesia - Import Licensing Regimes (New Zealand) and Australia - Tobacco Plain Packaging (Indonesia) (ASEAN - Australia - New Zealand FTA). ${ }^{33}$ Finally, Colombia - Spirits

\footnotetext{
${ }^{25}$ US - Supercalendered Paper (DS505); US - Agriculture Subsidies (DS357); US - COOL (DS484; DS486); Canada - Wine (DS520); US - Tuna II (Mexico) (DS381).

${ }^{26}$ Tratado de Libre Comercio entre los Estados Unidos Mexicanos y la República de Costa Rica, signed 5.4.1994, entered into force 1.1.1995, Chapter XVII.

${ }^{27}$ Acuerdo de Complementación Económica $n^{\circ} 35$ Celebrado entre los Gobiernos de los Estados Partes del Mercosur y el Gobierno de la República de Chile, signed on 25.6.1996, Annex 14. Protocol 21 to this Agreement, signed on 19.10.1999, establishes an arbitral procedure for dispute settlement, but is not in force.

28 Acuerdo de Complementación Económica suscrito entre los Gobiernos de la República Argentina, de la República Federativa del Brasil, de la República del Paraguay y de la República Oriental del Uruguay, Estados Partes del MERCOSUR, y el Gobierno de la República del Perú (ACE № 58), signed 30.11.2005, entered into force 6.2.2006, Annex VII.

${ }^{29}$ Acuerdo de Complementación Económica № 6 suscrito entre Argentina y México, signed 16.2.2007, entered into force 1.6.2007; Acuerdo de Complementación Económica $n^{\circ} 18$ (Mexico - Mercosur), signed 5.7.2002, entered into force 5.1.2006.

30 Comprehensive Economic Partnership Agreement between Japan and the Republic of India, signed 16.2.2011, entered into force 1.8.2011, Chapter 14.

${ }^{31}$ Charter of the Association of Southeast Asian Nations, 20.11.2007, entered into force 15.12.2008.

${ }^{32}$ ASEAN Protocol on Enhanced Dispute Settlement Mechanism, signed 29.11.2004, entered into force on the date of signature.

${ }^{33}$ Agreement Establishing the ASEAN - Australia - New Zealand Free Trade Area, signed 27.2.2009, entered into force 1.1.2010, Chapter 17.
} 
could in principle have been brought under the EU - Colombia/Peru FTA, which duplicates the GATT's national treatment obligation. ${ }^{34}$

\section{B. Political reasons: co-complainants, third parties and collective}

\section{pressure}

Not all disputes came to the WTO due to uncertainty in FTA adjudication. Some disputes could have been litigated under FTAs whose dispute settlement systems have been shown to operate. These disputes are Dominican Republic - Safeguard Measures, brought by no less than four of the Dominican Republic's CAFTA-DR partners (although the WTO report dates from 2012, and the Costa Rica v El Salvador CAFTA-DR dispute was initiated only in 2013); $;^{35}$ and EC - Seal Products (Norway), which could potentially have been taken to the Court of Justice of the European Union (CJEU) under the EEA Agreement. ${ }^{36}$ In the latter case, besides the possible doubts that Norway could have had with respect to the willingness of the CJEU to strike down the EU measure, the fact that Canada was a co-complainant in the WTO dispute which could not have filed a claim before the CJEU to enforce the EEA Agreement may have led Norway to pursue its claim before the WTO.

The same is true for many other WTO disputes which could in principle have been adjudicated under an FTA, but where WTO Members not parties to the FTA were cocomplainants. This is the case of the two disputes that could have been initiated under AANZFTA Chapter 17. In Australia - Tobacco Plain Packaging, co-complainants of Indonesia not parties to AANZFTA were Cuba, Honduras, the Dominican Republic and (originally) Ukraine. Similarly, in Indonesia - Horticultural and Animal Products, the United States was a co-complainant of New Zealand and not a party to AANZFTA.

This is also the case of the Argentina - Import Measures complaint from Mexico. The Argentinean measures could possibly have been challenged under the Argentina Mexico ALADI Agreement. However, this agreement applies to selected products only,

\footnotetext{
${ }^{34}$ Trade Agreement between the European Union and its Member States, of the One Part, and Colombia and Peru, of the Other Part, signed 26.6.2012, entered into force 8.1.2013, Article 21 and Title XII.

${ }^{35}$ See Panel Report, Dominican Republic - Safeguard Measures (DS415, DS416, DS417, DS418). The legality of this unilateral suspension itself could have been questioned under the FTA.

${ }^{36}$ Norway could start proceedings against the European Commission before the CJEU regarding compliance with the European Economic Area (EEA) Agreement, Articles 11 and 13. See EEA Agreement, Article 111.
} 
while a WTO condemnation applies across the board. ${ }^{37}$ More importantly in this case, Mexico withdrew its panel request almost immediately after filing it with the Dispute Settlement Body, but benefited from the final outcome. While Mexico still participated as a third party at the panel stage, ${ }^{38}$ it was the other three co-complainants (the United States, the European Union and Japan) who obtained the condemnation of Argentina's measures by a panel and the Appellate Body.

This highlights another advantage of WTO adjudication over FTA adjudication: institutional channels for Members not parties to the dispute to participate in the proceedings, as well as a political forum - the Dispute Settlement Body - in which they may express their views even without having participated. To participate in the proceedings, WTO Members may file parallel claims and participate as co-complainants. They may join the dispute as third parties, avoiding the confrontational aspect that is involved in filing a claim while still signaling their interest in the matter and providing their views on the subject-matter of the dispute. And, even if they refrain from participating in the proceedings, they are still entitled to press for compliance at DSB meetings.

Collective adoption of reports by the DSB entitles every Member to demand compliance. Adoption is often seen as a procedural quirk, given that it is virtually automatic. ${ }^{39}$ However, it may produce significant effects in terms of involving the WTO Membership in the dispute. WTO Members not only formally adopt reports but are also explicitly permitted to 'express their views'. ${ }^{40}$ Members may of course criticize the panel or Appellate Body report, but the vast majority of them uses DSB meetings as an opportunity to exhort wrongdoers to implement reports. Additionally, six months after adoption and failing an understanding between the parties, DSU Article 21.6 requires the DSB to begin collective surveillance of implementation, meaning that non-compliance with rulings will be compulsorily discussed

\footnotetext{
${ }^{37}$ The Argentina - Mexico and the Argentina - Mercosur Economic Complementation Agreements are 'Partial Scope Agreements', permissible under the WTO Enabling Clause. A dispute settlement system exists solely for the former, which covers around $40 \%$ of Mexican exports; the latter, which covers another $45 \%$ of exports, has no functioning dispute settlement mechanism. See Gustavo Stok, 'México y Argentina ampliarán productos para intercambio comercial', Expansión, 21 April 2017.

38 Appellate Body Report, Argentina - Import Measures (WT/DS438/R, WT/DS444/R, WT/DS445/R), para. 1.6.

39 Under DSU rules, an adjudicator's report will only fail to be adopted by the DSB if all WTO Members, including the winner of the dispute, consent to non-adoption. See DSU Articles 16.4, 17.14. Al panel reports with substantive findings, and all Appellate Body reports, have been adopted by the DSB.

${ }^{40}$ DSU, Articles 16.4, 17.14.
} 
before the whole WTO Membership at every ordinary meeting of the DSB. These apparent vestiges of the GATT's 'diplomatic' dispute settlement mechanism bring non-compliance to the attention of all WTO Members, and ensure that the violation is perceived not only as a violation vis-à-vis the particular Member(s) that happen(s) to have initiated the dispute but as a violation of the collectively agreed rule according to which Members will comply with WTO adjudicatory rulings. An offender's reputation is affected vis-à-vis all WTO Members, which will evaluate its trustworthiness in future trade negotiations and the need to abide by their WTO commitments towards it accordingly.

In sum, the 'collective' element of WTO adjudication is a powerful reason why Members would prefer WTO adjudication over FTA adjudication. These procedural elements provide Members with an opportunity to demonstrate interest in the dispute and press for compliance even when they have not been complainants. Other Members can dress their economic interest in seeing a specific policy change as a systemic interest in compliance. This is relevant because the value of adjudication as a remedy is significantly tied to its capacity to mobilize collective pressure against a violator.

\section{Adjudication as a remedy in trade agreements: the value of multilateralism}

\section{A. Remedies and compliance: reputation, reciprocity, retaliation}

Many analyses of remedies in trade agreements start from the procedural arrangements put in place by the dispute settlement rules of the DSU and (most) FTAs. Under these arrangements, retaliation appears as the last resort, as if the whole procedure were oriented towards obtaining an authorization to retaliate. A party that considers that a violation has taken place must first raise the matter bilaterally with the alleged wrongdoer. If bilateral negotiations are unsuccessful, it must then resort to adjudication. Only after an adjudicatory decision has been issued and in case of non-compliance with its terms may the aggrieved party lawfully retaliate against the wrongdoer.

Some assessments of dispute settlement infer from these legal arrangements that adjudication is largely an obstacle to the 'real' remedy of authorized trade retaliation, which would be capable of providing aggrieved parties with some form of compensation for the 
breach. $^{41}$ The various steps of WTO adjudication, including consultations, appeal, a period of time for implementation, and a procedure to assess compliance, thus appear as a burdensome requirement obstructing the ultimate goal of responding to a violation with trade retaliation. The adjudication process has thus been labelled 'a cost-free opportunity to delay compliance for several months' ${ }^{42}$ or 'a de facto escape clause for the duration of the legal proceedings'. ${ }^{43}$

However, the fact that the authorization for retaliation occupies the position of remedy of last resort in the legal process does not mean that it is the reason states resort to adjudication, or a means for the aggrieved party to make itself 'better off'. As discussed in Section 4 below, retaliation is rarely used when authorized. When used, it appears overwhelmingly as an instrument available to aggrieved parties to induce compliance, and not as a means to extract reparation from the wrongdoing Member. Despite analyses suggesting that retaliation could in some cases improve the terms of trade of the retaliating party, ${ }^{44}$ the practice of WTO Members is to use it as a means of inducing compliance. ${ }^{45}$

More importantly, the existence of a formal quasi-judicial remedy of authorized retaliation should not be taken to mean that it is trade agreements that create the possibility of retaliation. Together with the mechanisms of reputation and reciprocity, the prospect of retaliation is a key reason why states comply with their international obligations even in the absence of adjudication. Compulsory adjudication mechanisms were unknown until the early $20^{\text {th }}$ Century, and only became widespread from the 1970 s onwards. To this day, many international obligations are interpreted, applied and enforced purely at the inter-state level.

Without adjudication, states may comply with their obligations for several 'internal' reasons. Incorporation of international rules into domestic legislation may achieve compliance by ensuring that civil servants and domestic judges apply international norms; compliance may

\footnotetext{
${ }^{41}$ See e.g. Gary N. Horlick, 'Problems with the Compliance Structure of the WTO Dispute Resolution Process', in Daniel L. M. Kennedy and James D. Southwick (eds), The Political Economy of International Trade - Essays in Honour of Robert E. Hudec (CUP, 2002), 636-645; Rachel Brewster, 'The Remedy Gap: Institutional Design, Retaliation, and Trade Law Enforcement' (2011) 80 George Washington Law Review 102.

42 Horlick (n41), 637.

${ }^{43}$ Brewster (n41), 104.

${ }^{44}$ Kyle Bagwell, 'Remedies in the WTO: An Economic Perspective', in Merit E. Janow, Victoria J. Donaldson and Alan Yanovich (eds), WTO: Governance, Dispute Settlement \& Developing Countries (Juris 2008), pp. 733-770.

${ }^{45}$ See Section 4 below. See also Gregory Shaffer and Daniel Ganin, 'Extrapolating Purpose from Practice: Rebalancing or Inducing Compliance', in Chad P. Bown and Joost Pauwelyn (eds), The Law, Economics and Politics of Retaliation in WTO Dispute Settlement (CUP 2010), 73-85, 80-81.
} 
be perceived to be in the state's self-interest; and individuals in power may have an interest in presenting their governments internally and externally as 'good global citizens'. ${ }^{46}$ Where internal reasons for compliance would be insufficient to prevent a breach, the mechanisms of reputation, reciprocity and retaliation, which operate at the inter-state level, ensure a degree of compliance nonetheless. ${ }^{47}$

Reputation and reciprocity operate regardless of a conscious decision to punish the offender. Other states will treat a state that fails to abide by its commitments differently from what they would treat a reliable partner. Reputation affects the offender itself. When entering into agreements with known violators, other states will take this reputation into account and demand from a known violator more commitments, and more concrete assurances, than what they would have demanded from a state known for abiding by its obligations. Reciprocity affects the violated obligation. A state may feel less compelled to follow rules that have been violated often, in particular in subsequent interactions with a state that has not complied with its obligations in the past.

By contrast, retaliation involves a conscious decision by other states to sanction violations, affecting the offender's interests in order to force a change of conduct and discourage future breaches. Retaliation is therefore the fundamental instrument consciously employed by states to enforce international obligations. Although specifically regulated and incorporated into the adjudication process by trade agreements, retaliation is frequently employed by states in response to breaches of international obligations, without the need for previous adjudication. Under general international law, retaliation takes the form of countermeasures, i.e. unilateral non-performance of obligations owed to an alleged violator in response to a perceived breach, and of retorsions, i.e. unfriendly but lawful unilateral action taken towards the perceived offender. Unilateral retaliation therefore not only is not prohibited under general international law; it is specifically regulated as a means of

\footnotetext{
${ }^{46}$ See Thomas M. Franck, The Power of Legitimacy Among Nations (OUP 1990), 45-46; Harold Hongju Koh, 'Why Do Nations Obey International Law?' 106 Yale Law Journal (1997) 2599; Helen V. Milner, Interests, Institutions, and Information: Domestic Politics and International Relations (Princeton University Press 1997); Beth A. Simmons, Mobilizing for Human Rights: International Law in Domestic Politics (CUP 2009).

${ }^{47}$ The operation of the triad reputation-reciprocity- retaliation is described in detail in Andrew T. Guzman, How International Law Works: A Rational Choice Theory (OUP 2008). See also id, 'Reputation and International Law' UC Berkeley Public Law Research Paper No. 1112064, available at SSRN: https://ssrn.com/abstract=1112064; Joel P. Trachtman, The Economic Structure of International Law (Harvard University Press 2008).
} 
'implementation of the international responsibility of a state' in the International Law Commission's Articles on State Responsibility. ${ }^{48}$

\section{B. Remedies and the prohibition of unilateral retaliation}

The WTO Agreements and most FTAs establish a lex specialis to the general rules on implementation of responsibility, prohibiting unilateral retaliation and requiring parties that feel aggrieved by an alleged violation to resort to adjudication instead of retaliating. Retaliation is considered as a last resort in case the violation persists after adjudication. In the WTO, DSU Article 23.1 prohibits Members from taking unilateral measures to seek redress for violations of WTO law. Panels and the Appellate Body have found that this provision prohibits Members from taking any unilateral measures, lawful or unlawful, to respond to an alleged breach. ${ }^{49}$ Additionally, although most FTAs do not contain a provision equivalent to DSU Article 23.1, many international tribunals have inferred the existence of a similar rule prohibiting retaliation in other trade agreements that feature a sophisticated dispute settlement system. ${ }^{50}$

Importantly, the prohibition on unilateral retaliation does not fully prevent retaliation from taking place in practice. From a state's viewpoint, a decision to violate the prohibition on unilateral retaliation involves the same reasoning as a decision to violate another of its international obligations. The state may be inclined to violate the prohibition because it believes retaliation sends a stronger message than adjudication, or because retaliation operates immediately while adjudication will only produce a condemnation after years of litigation. It may choose to retaliate in manners that make it difficult to demonstrate the purpose of its acts, such as imposing seemingly legitimate requirements on imports of interest to the alleged violator. Or it may take seemingly unrelated action, such as cutting foreign aid or restricting cooperation programs that benefit an alleged offender. When a state is tempted to retaliate, the force of the prohibition to prevent unilateral retaliation will

\footnotetext{
${ }^{48}$ See International Law Commission, 'Draft articles on Responsibility of States for Internationally Wrongful Acts, with commentaries', ILC Yearbook 2001, II.2, at 128.

${ }^{49}$ Appellate Body Report, US - Certain EC Products, adopted 10 January 2001 (WT/DS165/AB/R), para. 111 (emphasis added); Panel Report, EC - Commercial Vessels, adopted 20 June 2005 (not appealed) (WT/DS301/R), paras. 7.207, 7.219.

${ }^{50}$ Mercosur Ad Hoc Arbitral Tribunal, Award No IX, 4 April 2003, 240; Court of Justice of the European Union, Commission v Luxemburg and Belgium, joint cases 90/63 and 91/63, ECR [1964] 625, 631; Arbitral Award, Air Service Agreement Arbitration (1978) 18 RIAA 417, 443.
} 
depend on the same elements that ordinarily lead to compliance where a state is tempted to violate its obligations - reciprocity, reputation and the prospect of retaliation.

Retaliation may be less relevant in inter-state disputes that do not involve an alleged violation. The states may, for example, disagree with respect to a specific issue and seek a decision from an impartial third party in order to prevent this disagreement from affecting their mutual relations. This is the case of the many voluntary submission of disputes, including border disputes, to international courts. The vast majority of trade disputes, however, involve primarily an alleged violation, such as a tariff, regulation or subsidy that is causing economic injury to the complainant. And, although each dispute must be examined on its own merits, in over $90 \%$ of WTO disputes panels and the Appellate Body have found that the defendant's measure was in violation of at least one provision of the WTO Agreements. ${ }^{51}$ This rate of victory for complainants is similar within FTAs. ${ }^{52}$

This extremely high rate of findings of breach indicates, first, that disputes are usually taken to adjudication only when there is significant certainty that a violation has occurred. Second, it indicates that the primary goal of most complainants is not to obtain an interpretation on which there is reasonable doubt, but to obtain an impartial third party's confirmation of what they are convinced is a violation. For the same reason, it is unlikely that defendants fail to settle in most cases because they believe the challenged measures are fully WTOconsistent - if they held this belief and were proven wrong $90 \%$ of the time, they could be expected to update their beliefs.

Other reasons for the defendants' failure to settle seem more likely. First, because WTO and most FTA rules on remedies do not allow adjudicators to award damages for the injury caused by violations, going through the adjudication process allows defendants to buy time and maintain for the duration of the procedure measures that they can anticipate will be considered WTO/FTA-inconsistent. This gives the domestic industry time to prepare for the increased competition that will come once the protectionist measure is lifted. Second, by allowing adjudication to take place, a respondent obtains the adjudicators' assessment of

\footnotetext{
${ }^{51}$ The website WorldTradeLaw.net finds that, out of 198 WTO panel and Appellate Body reports adopted so far, in only 19 was there no finding of violation (http://www.worldtradelaw.net/databases/violationlist.php, last accessed 3.6.2017).

${ }^{52}$ Out of twelve Mercosur arbitral awards (ten under the Ouro Preto Protocol, two under the Olivos Protocol), only two did not find violations (Brasília Protocol Awards Nos 3 and 10). Out of the three NAFTA panel reports issued under Chapter 20, only one (Tariffs Applied by Canada to Certain U.S. Origin Agricultural Products) did not find a violation. One of the two panel reports issued under CAFTA-DR (Costa Rica v El Salvador) found a violation.
} 
the extent to which its measures are WTO/FTA-inconsistent. While the condemnation of the measure is almost certain, there is wide scope for disagreement - including between the panel and the Appellate Body - as to what precisely the violation is, and as a consequence what compliance requires. A third possible reason is that a condemnation by an impartial international adjudicator affects the internal political process within the defendant, giving its government a reason to withdraw a measure that was of little or no interest to the government or the state in general but was politically difficult to withdraw because it benefited a specific organized or powerful constituency. Blaming the withdrawal on an international body, and on the threats of lower reputation, reciprocity and retaliation by other states, makes the change of conduct politically more palatable. ${ }^{53}$

\section{The choice between adjudication and retaliation}

Despite its potential effectiveness, retaliation is a risky move for the retaliating state. As any form of sanction, trade retaliation involves a cost for the party employing it. ${ }^{54}$ It affects domestic industries and consumers that rely on the targeted products. In order to be useful, retaliation requires both that the damage to the target be significant and that the cost for the retaliating party be not too high. For this reason, usually only 'large' states are able to employ it successfully. Even for these large states, however, applying retaliation has costs. It disrupts trade between the retaliating party and the violator, and is often described as the retaliating party 'shooting itself in the foot' to harm the wrongdoer. If the alleged violator perceives the retaliation itself as a breach, it may be tempted to counter-retaliate. While international law establishes parameters to avoid escalation of specific disputes into broader conflicts, the possibility of unilateral retaliation leading to such escalation always looms. ${ }^{55}$

Adjudication presents a useful alternative to retaliation if it can perform the same function of conveying a seriousness of purpose and drawing attention to the violation without requiring a state to shoot itself in the foot. As Christina Davis notes, this is precisely what WTO adjudication does: it 'provides states a way to convey to trade partners their commitment on a particular issue by means of a strategy that has moderate costs, short of

\footnotetext{
${ }^{53}$ See, Robert D. Putnam, 'Diplomacy and Domestic Politics: the Logic of Two-Level Games', 42 International Organization (1988) 427.

54 Daniel Drezner, 'The Hidden Hand of Economic Coercion' 57 International Organization (2003) 643, 645.

${ }^{55}$ In fact, Drezner argues that the prospect of escalation is a condition for small-scale retaliation to be effective. Daniel W. Drezner, The Sanctions Paradox: Economic Statecraft and International Relations (CUP 1999).
} 
risking a trade war through threats of unilateral retaliation. The filing of a complaint to the WTO substitutes for unilateralism'. ${ }^{56}$

In terms of international law's compliance-inducing mechanisms, the effect of adjudication is to hurt the wrongdoer's reputation, flagging it as an unreliable trade partner and triggering reputational costs and reciprocity from other states. Given the sovereign equality between the disputing parties, in the absence of a third-party statement each party's interpretation of the law and facts is equally valid. Other states tend to adopt a non-committal stance and merely encourage a solution. An adjudicatory ruling provides both the states involved and other states with a basis for treating the situation not as a mere difference of views but as a violation of an international engagement. Adjudication thus contributes to creating peer pressure and harming the wrongdoer's reputation, in particular if the party found in breach subsequently fails to comply with the ruling. At the same time, this means that the effect of adjudication is directly proportional to the effect that a decision produces on an audience other than the disputing governments.

\section{Adjudication and retaliation in the WTO and FTAs}

Some assessments of the choice of enforcement method are limited to the question of the choice of forum: whether a WTO Member faced with a measure that violates WTO law as well as an FTA (a common occurrence for trade-restrictive measures) will resort to dispute settlement under the DSU or under the FTA. Examining this question, Marc Busch concluded that states will choose a forum depending on whether they wish to establish a precedent at the multilateral level, as well as on their political inclination ('illiberal' states should choose FTAs over WTO). ${ }^{57}$

However, the potential choices of a state harmed by a violation include not only a choice of forum but also the choice whether to litigate at all. Rather than undergoing resourceconsuming adjudication procedures that will probably take two years to complete and will, in most cases, provide it with a mere confirmation that its claims are justified, a complainant might be tempted to retaliate unilaterally and immediately. In fact, international relations scholars argue that compliance with international agreements is maintained in large

\footnotetext{
${ }^{56}$ Christina L. Davis, Why Adjudicate? Enforcing Trade Rules in the WTO (Princeton University Press 2012), 53.

${ }^{57}$ Marc L. Busch, 'Overlapping Institutions, Forum Shopping, and Dispute Settlement in International Trade', 61 International Organization (2007) 735.
} 
measure by the threat that violations will lead to immediate, tit-for-tat retaliation by other parties. $^{58}$

Thus, following unsuccessful negotiations, a WTO Member whose economic interests are harmed by a violation of trade rules by another Member that is its partner in an FTA partners has three possible courses of action: WTO adjudication, FTA adjudication, or retaliation. ${ }^{59}$ As discussed above, several elements may influence the choice between litigating a case before the WTO or before an FTA adjudicator, including the substantive rules applicable, the expected quality of the decision and the speed at which a decision can be obtained. An FTA may establish a procedure that is in principle speedier than WTO adjudication, since most FTAs do not permit appeals and establish periods of time for compliance much shorter than the DSU's standard fifteen months. Additionally, many FTAs allow retaliation by an aggrieved party immediately upon the end of the period allotted for compliance, while under DSU rules retaliation is permitted only following a formal authorization, issued only after compliance proceedings and an arbitration concerning the permissible level of retaliation. On the other hand, FTAs provide less certainty to the complainant regarding the procedure for composing the panel and conducting litigation, as well as the quality of the final decision.

While these legal procedural factors explain some decisions to resort to the WTO rather than to FTAs, the complete dominance of WTO litigation over FTA litigation indicates that the political factors play an important role as well. Indeed, the multiplication of dispute settlement proceedings within FTAs, which could have led to more disputes as these agreements establish tighter rules than the WTO does, in practice has resulted in less WTO disputes between FTA partners and no corresponding increase in FTA disputes. This may be partially because FTA negotiations serves to 'iron out' differences, with parties agreeing to tear down barriers to each other's exports (and perhaps agreeing, formally or not, to tolerate some other barriers). ${ }^{60}$ This 'ironing out' of differences may be a relevant factor in the first few years after an FTA is signed, but it is unlikely that it explains the total absence of

\footnotetext{
58 Robert Axelrod, The Evolution of Cooperation (Basic 1984), 176; Robert O. Keohane, 'Reciprocity in International Relations', 40 International Organization (1986) 1.

${ }^{59}$ This assumes, of course, that the measure violates both the FTA and the WTO Agreements. Even if it does not, however, the dilemma between WTO adjudication/retaliation and FTA adjudication/retaliation persists.

${ }^{60}$ Petros C. Mavroidis and André Sapir, 'Dial FTAs for Peace: The Influence of Preferential Trade Agreements on Litigation between Prading Partners' http://indianeconomy.columbia.edu/sites/default/files/paper4-dial_ptas for peace.pdf
} 
disputes ten years after the signature. A FTA certainly does not prevent the subsequent adoption of measures that may be considered as both WTO-inconsistent and FTAinconsistent.

A structural difference between WTO adjudication and FTA adjudication that might help explain the success of the former is the multilateral character of WTO adjudication. This involves, on the one hand, greater attention given to a WTO dispute settlement report than what would be received by a ruling from a bilateral panel. Internally, a report that receives the imprint of the World Trade Organization can be expected to receive far more media attention than a report or award issued under a bilateral trade agreement the public and the media itself are unfamiliar with. Equally importantly, externally, the fact that the report is subsequently adopted by the entire WTO Membership at the Dispute Settlement Body (DSB) makes it a collective decision of the Membership, and continued violation an issue of concern to all Members.

\section{E. Retaliation, reputation and the 'missing' FTA disputes}

The result of the WTO's unique breed of institutional adjudication and collective surveillance is that a Member found in breach of its WTO obligations is constantly subject to peer pressure, which reaches particularly acute levels when new decisions are issued (i.e. when a panel and the Appellate Body decide on non-compliance and when the arbitrators issues a decision on retaliation). This positive effect on WTO compliance of collective peer pressure has often been noted. Robert Hudec has found that this 'community pressure' was the key to the success of GATT litigation, ${ }^{61}$ and Giovanni Maggi has hinted at the existence of 'multilateral enforcement pressures' ${ }^{\prime 2}$ which would explain compliance by large Members that could brush off threats of retaliation from smaller ones. Joost Pauwelyn has also noted that persistent violation generates 'community costs' for the wrongdoer. ${ }^{63}$

\footnotetext{
${ }^{61}$ Robert E. Hudec, 'Broadening the Scope of Remedies in WTO Dispute Settlement', in Friedl Weiss \& Jochem Wiers (eds), Improving WTO Dispute Settlement Procedures (Cameron May 2000), 345-376.

${ }^{62}$ Giovanni Maggi, 'The Role of Multilateral Institutions in International Trade Cooperation', 89 The American Economic Review (1999) 190, 191-192.

63 Joost Pauwelyn, Optimal Protection of International Law: Navigating between European Absolutism and American Voluntarism (CUP 2008), 128.
} 
Contrasting with the multilateral WTO dispute settlement system, in adjudication under FTA the adjudicators are usually separated from the political decision-making bodies. ${ }^{64}$ While an organ may be specifically required to consider cases of non-implementation, such an organ would seem superfluous in bilateral FTAs for purposes of generating additional community pressure, since the two parties would be aware of existing issues (meetings may of course allow communication and serve as a forum for bilateral pressure and negotiations). Even in 'minilateral' FTAs composed of a handful of parties, trade disputes may be seen as matters of concern to the parties to the dispute only, with other parties choosing to stay out of the matter. Thus, while the product of adjudication may appear similar in a bilateral and in a multilateral setting, its ability to affect the reputation of the offender may be very different depending on the forum chosen.

On the other hand, the threat of retaliation operates similarly in a bilateral and in a multilateral setting. Its ability to induce compliance depends essentially on the size of the retaliating party's market, and on the relation between the costs that the retaliating party imposes on the offender (by shutting some of the offender's exports out of its market) and the cost the retaliating party suffers from the retaliation (by denying its companies and consumers access to the violator's products). Importantly, these costs are produced whether or not retaliation is preceded by adjudication, and whether or not it takes place lawfully. In fact, the time required for adjudication hampers the utility of retaliation as a deterrent of breach. If FTA adjudication cannot create reputational costs comparable to those created under the WTO system, an aggrieved party may be tempted not only to choose WTO adjudication over FTA adjudication, but also to choose unilateral retaliation over FTA adjudication.

There is significant evidence that unilateral retaliation remains relevant even within the WTO setting, and that bilateral understandings over norm-compliance take place within broader negotiations concerning reciprocal mutual trade relations. ${ }^{65}$ It is not uncommon for mutually agreed solutions to disputes to include provisions that bear little relation with the object of the dispute the mutually agreed solution refers to. ${ }^{66}$ The lack of use of FTA dispute

\footnotetext{
${ }^{64}$ In rare cases, the decisions of adjudicators are subject to appeal to the political bodies. See Agreement on South Asian Free Trade Area (SAFTA), Article 20.9.

${ }^{65}$ See Chad P. Bown and Rachel McCulloch, 'U.S.-Japan and U.S.-China trade conflict: Export growth, reciprocity, and the international trading system' 20 Journal of Asian Economics (2009) 669-687.

${ }^{66}$ See e.g. Memorandum of Understanding between the Government of the United States of America and the
} 
settlement, coupled with a reduction in WTO dispute settlement between Members that sign FTAs, indicates that FTAs may in fact increase the extent to which Members respond to breaches with unilateral retaliation rather than resort to adjudication.

Among FTAs which have not seen any recent use, the case of Mercosur is particularly interesting because its dispute settlement system can be resorted to unilaterally by any Member. Aside from the non-trade dispute concerning Paraguay's suspension from the bloc's decision-making bodies in 2012, 2006 was the last year in which Mercosur Members initiated formal disputes against each other, both in the WTO (the request for consultations brought by Argentina in Brazil - Anti-Dumping Measures on Resins) and under the Mercosur dispute settlement system (the Roadblocks case brought by Uruguay against Argentina). ${ }^{67}$ No intra-Mercosur disputes have been brought at all, before either forum, during the ten years under examination.

This did not occur for a lack of new trade barriers. Around the world, responses to the 2008 global economic downturn have included an increase in protectionist policies, and Mercosur countries were no exception. ${ }^{68}$ Argentina created a system of non-automatic licenses that, as the Appellate Body put it, was avowedly aimed at 'inter alia, substituting imports for domestically produced goods and reducing or eliminating trade deficits'. ${ }^{69}$ Although Argentina is a key trade partner for Brazil, Paraguay and Uruguay, none of the four complainants in Argentina - Measures Affecting the Importation of Goods were Mercosur Members. Instead, one year before the European Union started consultations on the matter (followed by the United States, Japan and Mexico), Brazil responded by applying a similar measure with respect to cars, affecting mainly Argentinian exports, ${ }^{70}$ and subsequently tightened restrictions solely for Argentinian cars. ${ }^{71}$ It took three years for the two Mercosur

Government of the Republic of Indonesia, 3 Oct 2014, https://ustr.gov/sites/default/files/US\%

20Indo\%20MOU.pdf (accessed 28 April 2017); Joint Communication from Brazil and the United States, 31 August 2010 (WT/DS267/45), III.3.

${ }^{67}$ Mercosur Ad Hoc Tribunal, Arbitral Award, Roadblocks, 6 September 2006. The alleged breach was the construction of pulp mills on River Uruguay, later considered by the International Court of Justice not to have been a breach (Pulp Mills, ICJ Reports 2010, p. 4).

${ }^{68}$ Since 2009, the WTO monitors trade-restrictive measures taken by G20 countries, which include Brazil and Argentina, and issues biannual reports. See https://www.wto.org/english/tratop e/tpr e/trade monitoring e.htm.

${ }^{69}$ Appellate Body Report, Argentina - Measures Affecting the Importation of Goods, para. 4.14; Panel Reports, Argentina - Measures Affecting the Importation of Goods, para. 6.119.

70 'Brasil retalia Argentina e impõe barreira à importação de carros', O Estado de S. Paulo, 13 May 2011

${ }^{71}$ Raquel Landim, 'Brasil atrasa importação de carro argentino', O Estado de S. Paulo, 25 June 2012. 
Members to enter into an agreement (currently in force) to pursue 'managed trade' ${ }^{72}$ The 'involution' of responses to trade disputes in Mercosur, from adjudication to tit-for-tat unilateral retaliation, was widely reported on.

Choosing retaliation instead of adjudication is not an exclusivity of Mercosur Members. In response to the United States' blocking of the constitution of a NAFTA panel in the Sugar dispute, Mexico prohibited importation of US-produced high-fructose corn syrup as well as of products containing it. When the United States challenged the latter restriction before the WTO, Mexico (unsuccessfully) argued that the dispute was 'inextricably linked to a broader dispute regarding access of Mexican sugar to the United States' market under the NAFTA', ${ }^{73}$ and violating its WTO obligations was its means of enforcing a NAFTA obligation. The issue was solved, through an agreement for mutual liberalization, only after the Appellate Body issued a report condemning the Mexican measure. ${ }^{74}$

These cases show that, treaty texts aside, unlawful trade retaliation remains a possibility for governments and diplomats. The fact that in some cases (NAFTA) measures are challenged before the WTO, while in other cases (Mercosur) disputes are entirely dealt with through retaliation and negotiations, may mean that FTAs in fact lead parties to settle their subsequent disputes politically - through resort to unlawful threats and retaliation. It would seem that, when disputes are formalized and taken to adjudication, they are taken to the WTO.

\section{The value of WTO adjudication: evidence from the practice of retaliation}

While studies suggest that WTO Members do resort to retaliation in spite of the prohibition in DSU Article 23.1, resort to adjudication is both common and, when used, successful in producing the settlement of the disputes. The practice of Members with WTO adjudication suggests that, within the framework of the dispute settlement system, retaliation operates precisely as the 'last resort' that the DSU states it should be. ${ }^{75}$

\footnotetext{
${ }^{72}$ Felipe Gutierrez, 'Brasil faz acordo sobre carro com Argentina', Folha de S. Paulo, 12 June 2014.

${ }^{73}$ Appellate Body report, Mexico - Soft Drinks, para. 42.

${ }^{74}$ Magda Kornis, 'U.S. Corn Sweeteners and Mexican Sugar: Agreement at Last!', Journal of International Commerce and Economics, December 2006, https://www.usitc.gov/publications/332/journals/corn sweeteners.pdf

${ }^{75}$ DSU Article 3.7.
} 


\section{A. Before the authorization: early settlements and sequencing agreements}

First of all, disputes that do get to the stage of retaliation are a small fraction of the total number of disputes brought before the WTO. The vast majority of WTO disputes are settled long before the retaliation stage is attained. This can be shown by an assessment of the first 386 disputes brought to the WTO. These are all the disputes initiated prior to the two last disputes to reach the retaliation stage, in 2015 and 2017 respectively: US - COOL ${ }^{76}$ and US Tuna $\| .{ }^{77}$ Since the arbitrator's decision authorizing retaliation in US - Tuna II was issued 8.5 years after the request for consultations - a record high ${ }^{78}$ - in principle every dispute initiated before these ones could have reached the stage of retaliation. ${ }^{79}$ The table below provides data on the number of disputes that reached each stage:

Table 2 - Disputes (DS1-DS386) by stage reached (July 2017)

\begin{tabular}{|lccc|}
\hline Stage of dispute & \# of disputes & $\%$ of consultations & $\%$ of DSB reports \\
\hline Consultations & 386 & $100 \%$ & - \\
\hline Panels established & 279 & $72 \%$ & - \\
\hline DSB reports adopted & 162 & $42 \%$ & $100 \%$ \\
\hline Article 21.3(c) arbitrations & 45 & $12 \%$ & $28 \%$ \\
\hline Compliance reports adopted & $26 *$ & $7 \%$ & $16 \%$ \\
\hline Article 22.6 arbitrations & $13 *$ & $3 \%$ & $8 \%$ \\
\hline
\end{tabular}

* Does not include second recourses to Article 21.5.

* The 13 reports correspond to eleven disputes, since challenges by co-complainants have been given different DS numbers in EC-Hormones and US - COOL.

Of the first 386 disputes initiated, $28 \%$ were settled or discontinued without the establishment of a panel; $58 \%$ were settled or discontinued before the adoption of a DSB report. Of the 162 reports adopted, only 26 (16\%) were followed by a dispute on compliance under Article 21.5; thus, in $84 \%$ of cases, the complainant either was satisfied that

\footnotetext{
76 Decisions by the Arbitrator (Article 22.6), US - COOL, 7 December 2015. Consultations requested on 1 December 2008 (S384) and 17 December 2008 (DS386).

77 Decision by the Arbitrator (Article 22.6), US - Tuna II (Mexico), 25 April 2017. Consultations requested on 24 October 2008.

${ }^{78}$ See table 3 below.

79 The likely exceptions are the two Large Civil Aircraft disputes concerning subsidies to Boeing and Airbus (DS316 and DS353). Disputes initiated after 2008 should more than compensate for these two disputes, since retaliation in US - COOL was authorized one year and a half before retaliation in US - Tuna II.
} 
compliance followed adjudication or reached an alternative arrangement with the violator. Only in thirteen disputes (8\%) did the procedure reach the stage at which arbitration on retaliation was necessary. If adjudication did not produce any effects, many if not most defendants could be expected to drag their feet and wait for the threat of retaliation to materialize before taking any measures to address the complainant's grievances. Instead, in $92 \%$ of the disputes up to DS386 defendants either complied or settled the dispute before reaching the stage at which authorized retaliation became a concrete possibility.

Where disputes have reached the retaliation stage, this usually took place after a long procedure involving one original report, one compliance report and one arbitration on the level of permissible retaliation. Table 3 summarizes the time it took for each dispute to reach the stage of authorized retaliation.

Table 3 - Time taken to reach the stages of a dispute

\begin{tabular}{|c|c|c|c|c|c|}
\hline Dispute & Started & Report & RPT & 21.5 Report & 22.6 Arbitration \\
\hline EC-Hormones & 1996 & 2 years & 15 months & & 3 years, 5 months \\
\hline EC-Bananas III & 1996 & 1 year, 7 months & 15 months & $\begin{array}{l}3 \text { years, } 3 \\
\text { months }\end{array}$ & 4 years, 1 month \\
\hline Brazil - Aircraft & 1996 & 3 years, 2 months & & $\begin{array}{l}3 \text { years, } 10 \\
\text { months }\end{array}$ & 4 years, 2 months \\
\hline$U S-F S C$ & 1997 & 2 years, 4 months & & $\begin{array}{l}3 \text { years, } 9 \\
\text { months }\end{array}$ & 5 years, 5 months \\
\hline $\begin{array}{l}\text { US - Byrd } \\
\text { Amendment }\end{array}$ & 2001 & 2 year, 1 month & 11 months & & 3 years, 8 months \\
\hline US - 1916 AD Act & 1998 & 2 years, 3 months & 10 months & & 5 years, 8 months \\
\hline Canada-Aircraft & 2001 & 1 year & & & 2 years \\
\hline US - Cotton & 2002 & 2 years, 5 months & & $\begin{array}{l}5 \text { years, } 2 \\
\text { months }\end{array}$ & 6 years, 11 months \\
\hline US - Gambling & 2003 & 2 years, 1 month & 11 months & 4 years & 4 years, 9 months \\
\hline US - Tuna II & 2008 & 3 years, 7 months & & $\begin{array}{l}6 \text { years, } 5 \\
\text { months }\end{array}$ & 8 years, 6 months \\
\hline US - COOL & 2008 & 3 years, 7 months & 10 months & $\begin{array}{l}5 \text { years, } 10 \\
\text { months }\end{array}$ & 7 years \\
\hline
\end{tabular}

Besides the long period it takes to get to the stage of retaliation (on average, 5 years and 4 months), Members' conduct at the pre-retaliation procedure also indicates that they do not rush to obtain the authorization to retaliate. Delays in dispute settlement itself are often accepted while the parties negotiate an alternative solution. After a condemnatory panel or 
Appellate Body report, parties usually agree on a reasonable period of time for the wrongdoer to comply. Out of 26 disputes that have reached the stage of compliance panels to date, only in 10 did the parties require arbitration to agree on the reasonable period of time (RPT), in the remaining ones, the RPT was agreed upon consensually. Once this RPT expires, in most cases the parties sign 'sequencing agreements' whereby the retaliation procedure is stayed until a DSB report on compliance is issued.

This is significant because the compliance stage adds 2 years to disputes on average, ${ }^{80}$ and in practice members acting aggressively may request (and obtain) the authorization to retaliate without previously having a compliance panel determine non-compliance. Although unfriendly, such an aggressive strategy could provide the complainant with an authorization to retaliate early on. However, the only case in which a claimant acted this aggressively was the United States' 1999 retaliation request in EC - Bananas (Indonesia threatened to replicate this move in 2013 in US - Clove Cigarettes, before reaching a mutually agreed solution). All other disputes in which an offender claimed to have complied were referred to a compliance panel under Article 21.5. Other than in cases in which wrongdoers admitted to not having taken any measures to comply, parties entered into sequencing agreements in all disputes that ultimately led to an authorization for retaliation. ${ }^{81}$

\section{B. Upon authorization: under-retaliation}

So far, every dispute in which retaliation was authorized was preceded by an arbitration on the permissible level of retaliation under DSU Article 22.6. The dynamic of these arbitrations concerning retaliation is such that complainants often request an authorization to apply retaliation at a very high level (usually measured in US dollars), while the wrongdoer proposes a very low level. The arbitrator then determines what level would be equivalent to the nullification or impairment caused by the measure. This could lead to the impression that, once retaliation is authorized, the complainant would (i) rush to apply it; and (ii) apply it at the highest permissible level.

\footnotetext{
${ }^{80}$ This is the difference between the average length of disputes in which an Decision on retaliation was issued without a compliance panel and the average length of disputes in which a Decision on retaliation was issued after a compliance panel.

${ }^{81}$ See WT/DS46/13 (Brazil - Aircraft), WT/DS108/12 (US - FSC), WT/285/16 (US - Gambling), WT/267/22 (US Cotton), , WT/DS381/19 (US - Tuna II (Mexico)), WT/DS384/25 (US - COOL (Canada)), WT/DS386/24 (US COOL (Mexico)).
} 
This has rarely happened in practice. With respect to the timing, in the particularly striking case of US - Gambling, Antigua only requested the DSB to authorize retaliation five years after the arbitrator issued a decision determining the permissible level of retaliation. While normally complainants will request and obtain the authorization within two months of the arbitrator's decision, this does not mean that they will follow suit an apply the authorized retaliation. In eight out of the thirteen disputes in which it was authorized, retaliation was never applied. ${ }^{82}$ In EC - Bananas (Ecuador), Brazil - Aircraft, Canada - Aircraft II, US Gambling, US - Cotton, and US - COOL, threats of retaliation never materialized. In US Tuna II, the DSB issued the authorization for Mexico to retaliate the United States in May 2017; as of July 2017, Mexico appears to be waiting for the results of a second Article 21.5 report, which, if appealed, should not be adopted before the end of the year. In the meantime, if retaliation were the 'real' remedy, Mexico would arguably be 'wasting' its entitlement to a remedy.

When they do adopt retaliation measures, WTO Members used their entitlement strategically, with the clear aim of inducing compliance or obtaining compensation through the threat of retaliation. In US - FSC, the EU was granted an authorization to apply retaliation at a very high level - over 4 billion dollars per year. Instead of imposing correspondingly high additional duties on US exports, the EU initially fixed the amount of additional duties at a low level (5\%) and determined that the value of this retaliation would increase by an additional $1 \%$ for every month in the subsequent months. ${ }^{83} \mathrm{~A}$ few months after the measures started being applied, the US passed legislation intended to implement the ruling, to which the EU responded (even if it did not agree that this achieved compliance) by suspending the retaliation measures. In US - Cotton, Brazil was entitled to apply a level of retaliation that attained 800 million dollars a year. Instead of implementing retaliation measures with immediate effect, it enacted 'ticking clock' legislation providing that retaliation would start being applied on 7 April $2010 .{ }^{84}$ This brought the United States to the

\footnotetext{
${ }^{82}$ Retaliation was authorized separately for different complaiants in the same dispute in US - COOL (for Mexico and Canada), EC-Hormones (for the US and Canada) and EC-Bananas (for the US and Ecuador). In US - Byrd Amendment, eight complainants were authorized to retaliate (the EC, Brazil, Chile, India, Japan, Korea, Mexico and Canada).

${ }^{83}$ Council Regulation (EC) No 2193/2003, 8 December 2003, Article 2.

${ }^{84}$ Communication from Brazil, WT/DS267/43, 12 March 2010.
} 
negotiating table, leading to a provisional arrangement on 6 April $2010^{85}$ and subsequently to a compensation agreement involving trade measures and financial contributions. ${ }^{86}$

Only on three occasions, two in 1999 and one in 2004, was retaliation applied at the maximum levels authorized. In 1999, the United States adopted retaliation at the maximum permitted levels against the European Union (then EC) in EC - Bananas (US) and EC Hormones (US). In 2004, four out of the eleven complainants in US - Byrd Amendment (the EC, Japan, Canada, and Mexico) applied retaliation 'collectively' and at the highest level authorized. Only in the latter case was retaliation effective in inducing compliance immediately. The EC - Bananas and EC - Hormones disputes dragged on for over a decade while retaliation was being applied - which may help explain why the US has ceased its aggressive use of retaliation (or at least of authorized retaliation).

\section{After the authorization: second recourse to Article $\mathbf{2 1 . 5}$}

Perhaps the clearest evidence of the preference given to adjudication over retaliation by Members that resort to WTO dispute settlement is the decision by aggrieved members to engage in a second compliance adjudication procedure, after receiving from the DSB an authorization to apply retaliation. In Brazil - Aircraft, US - FSC, and EC - Bananas, complainants requested a second 21.5 panel (a so-called 21.5 // panel) after retaliation was authorized. In the latter two cases, complainants suspended retaliation during the compliance panel and Appellate Body proceedings. ${ }^{87}$ Although in US - Tuna /I the second Article 21.5 panel was requested by the United States (the defendant), Mexico appears to be waiting for the result of this panel to announce its retaliation plans. This use of second Article 21.5 procedures suggests that, once Members have decided to resort to WTO adjudication, they prefer adjudication to retaliation. While they are entitled to pursue retaliation until there is a multilateral declaration of compliance, ${ }^{88}$ faced with a change in the underlying measure Members voluntarily choose to suspend retaliation (or never adopt it) and request adjudication a third time on the same dispute.

\footnotetext{
${ }^{85}$ Sewell Chan, "U.S and Brazil Reach Agreement on Cotton Dispute", New York Times, 6 April 2010.

${ }^{86}$ Joint Communication from Brazil and the United States, WT/DS267/45, 31 August 2010.

${ }^{87}$ By contrast, in EC - Hormones, the US and Canada rejected the EC's unilateral declaration that it had complied with the recommendations and rulings of the DSB and maintained retaliation measures, forcing the EC to seek (unsuccessfully) a confirmation of compliance through a new recourse to dispute settlement.

${ }^{88}$ See Appellate Body Report, US/Canada - Continued Suspension, paras. 381-384.
} 


\section{Conclusion}

Both the WTO Agreements and FTAs are known for having 'teeth' ${ }^{89}$ The teeth include, on the one hand, adjudication procedures that alleged wrongdoers may not block; on the other hand, a potential authorization for aggrieved parties to retaliate in case of failure to comply with the adjudicator's decision. These two means of enforcement operate by mobilizing distinct forces for compliance. Adjudication publicizes and highlights the violation, harming the offender's reputation as a reliable trade partner. Trade retaliation (and threats thereof) denies the violator's producers access to the retaliating party's market.

Retaliation is an integral part of inter-state negotiations. Trade agreements provide states wishing to escalate a dispute with an alternative to retaliation: adjudication. However, the potential choices of a state harmed by a violation include not only a choice of forum - i.e. whether a to litigate before the WTO or an FTA - but also a choice whether to litigate at all. This choice takes into account, on the one hand, the expected value of adjudication, and possibly of the authorization to retaliate, and on the other hand the possibility of direct negotiations, including threats of (overt or covert) retaliation.

Retaliation is sometimes seen as the main remedy in trade disputes. An assessment of FTA and WTO practice, however, demonstrates that FTA litigation, which should in principle produce a quicker authorization to retaliate with less judicial oversight, is almost not resorted to. At the same time, at the WTO Members favor the allegedly weaker remedy adjudication - over the allegedly stronger one of retaliation. The latter is treated in practice as the last resort that the drafters of the DSU considered it should be.

The discrepancy between the vibrant practice of WTO adjudication and the virtual absence of FTA adjudication (in 2007-2016) may be explained in part by the collective character that the DSU imprints on WTO disputes, which leads to community pressure and not only pressure from the complainant. If adjudication generates enough community pressure, retaliation becomes relatively less attractive as a means to induce compliance; it is mostly attractive as a means of escalating the dispute, once the alternative of adjudication has been exhausted. In the absence or ineffectiveness of community pressure - a common situation in FTAs - adjudication is a less powerful remedy, and retaliation becomes a more attractive

\footnotetext{
${ }^{89}$ Miguel Montana i Mora, 'A GATT With Teeth: Law Wins Over Politics in the Resolution of International Trade Disputes' 31 Columbia Journal of Transnational Law (1993) 131.
} 
Geraldo Vidigal

alternative. Combined with the specific legal features of the different FTAs, which tend to have more limited coverage and less clear procedural rules, this helps explain why the proliferation of FTAs has led to less litigation before the WTO but not to more litigation under FTA dispute settlement procedures. 